\title{
Addressing the Unmet Need for ART among HIV+ Women and Newborns in Cameroon through Strengthening the Supply Chain of PMTCT Commodities
}

\author{
Nfor E., ${ }^{1, *}$, K. Kakanda ${ }^{1}$, G. Buki ${ }^{2}$, A. Kane ${ }^{3}$, J. Dongang ${ }^{3}$ \\ ${ }^{1}$ Management Sciences for Health, Pharmaceuticals and Health Technologies Group/SIAPS, USA \\ ${ }^{2}$ Management Sciences for Health, Pharmaceuticals and Health Technologies Group/SIAPS, Rwanda \\ ${ }^{3}$ Management Sciences for Health, Pharmaceuticals and Health Technologies Group/SIAPS, Cameroon
}

Copyright $(\subset) 2015$ by authors, all rights reserved. Authors agree that this article remains permanently open access under the terms of the Creative Commons Attribution License 4.0 International License

\begin{abstract}
Background: The Government of Cameroon and its partners have made major investments in the last decade in prevention, treatment, and care of HIV-infected patients. However, unmet need for antiretroviral therapy (ART) among HIV-positive pregnant women remains high at $66 \%$. Critical to satisfying this need is ensuring adequate availability of prevention of mother-to-child transmission (PMTCT) commodities for rollout of new Option $\mathrm{B}+$ guidelines. The Cameroon supply system consists of a cost recovery system for essential medicines and other health commodities and a free-of-charge system for priority commodities including those for PMTCT and ART. This study examines options for improving the supply and availability of these commodities. Method: Supply chain (SC) operational data was collected in July 2014 from central (CENAME) and 4 regional warehouses (CAPRs); 10 district stores; and 30 service delivery points (SDPs), including ART and PMTCT sites. The study also included seven central private-sector logistics firms. In addition, $\mathrm{SC}$ cost data was obtained from CENAME and CAPRs financial statements audited in 2013. Data collected served for analysis of three options to improve effectiveness of delivering PMTCT commodities, based on the four variables detailed in Figure 2.4.1. Results: Asset utilization within the cost recovery system ranged between $73 \%$ and $89 \%$ while inventory turnover was at 1.5 . Therefore, a reliable supply of medicines to SDPs is ensured. However, for PMTCT and ART commodities, distribution to the SDPs was unreliable (in $2013,40 \%$ of prescriptions remained unfilled). Meanwhile, results of the options analysis indicated that the model of CAPRs delivering PMTCT commodities to SDPs was the most desirable. Although the distance traveled was higher, the need for network storage space was minimal. Moreover, its total cost and human resource requirements were more favorable. Conclusion: As a result of disseminating the findings, the Ministry of Health adopted Option 2. PMTCT free-of-charge commodities are also amenable to being managed within the existing effective cost recovery system.
\end{abstract}

Keywords Supply Chain Options Analysis, Prevention of Mother to Child Transmission of HIV (PMTCT), PMTCT Option B+, Warehousing Costs, Transportation Costs, Return on Assets, Inventory Turnover Rate, Storage Capacity, Total Supply Chain Cost, Logistics Costs, Waste Management, Antiretroviral Medicines

\section{Introduction}

HIV, malaria, and unintended fertility constitute barriers to the achievement of Millennium Development Goals 4, 5, and 6 in Cameroon.[1][2] The national health sector strategy 2011-2015 describes control targets for these diseases, for example, elimination of mother-to-child transmission of HIV by 2015. The national strategy to scale up prevention of mother-to-child transmission (PMTCT) Option B+ includes plan to move from 22 pilot sites in two out of ten regions to 3000 sites nationwide.[3][4]

A national facilities survey conducted in 2012 revealed the following in regard to prevention of HIV PMTCT service provision [5]:

- PMTCT guidelines were available at less than $50 \%$ of the health facilities surveyed.

- On average, $12.3 \%$ of health facilities, mostly in Southwest, Northwest, Littoral, and Center regions, were following the new PMTCT guidelines adopted in 2010.

- Of health facilities, $46.8 \%(864 / 2,096)$ were providing HIV testing, prophylaxis, and antiretroviral treatment (ART) for HIV seropositive pregnant women. Unmet needs for ART for HIV-positive pregnant women varied from $53 \%$ to $66 \%$.

- Among the 6,111 health care providers surveyed, only $55 \%$ were trained in PMTCT service provision.

- The average acceptance rate for HIV testing among pregnant women was $88 \%$ with higher rates observed in 
the regions of Adamawa, Centre, Littoral, Southwest, and West.

Besides infectious diseases, unintended fertility fuels a rate of population growth that is outpacing efforts to meet the social needs and to achieve national development goals. Closely spaced and ill-timed pregnancies and births contribute to high infant mortality rate, and infants of mothers who die as a result of giving birth have a greater risk of mortality and poor health status. The rate of under-five mortality in Cameroon was 95 deaths per 1,000 live births in 2012 and in the period 2007-2011 Cameroon had a reported maternal mortality ratio of 670 deaths per 100,000 live births. [6]

Cameroon's health system is organized according to the tenets of primary health care with three levels: central, intermediate, and operational levels. Its supply system mirrors these three tiers, including a Central Medical Store Centre Nationale d'Approvisionnement en Médicaments et Consommables Médicaux Essentiels (CENAME), 10 regional stores (CAPRs), and about 3,000 health facilities, or Service Delivery Points (SDPs). However, the supply network for PMTCT commodities includes an additional tier, the district health service, making it a four-tier network.

CENAME's primary mission is to:

- Ensure availability of all essential medicines and other health commodities as part of a cost-recovery supply system, including products for priority public health programs such as HIV and AIDs, malaria, and tuberculosis that are dispensed free of charge to end users

- Supply regional medical stores known as CAPRs (Centre d'Approvisionnement en Médicaments Essentials et Consommables Médicaux de Region), with essential medicines and other health commodities at the best quality/price ratio

- Supply antiretroviral (ARV) medicines and other commodities for PMTCT and ART to CAPRs on a quarterly basis

CENAME receives a $10 \%$ management fee for ARVs procured with funding from the government and the Global Fund to Fight AIDS, Tuberculosis and Malaria (Global Fund), and a fee of $7.5 \%$ for second-line and pediatric ARVs procured with funding from the Clinton Foundation's Health Access Initiative (CHAI).

CENAME and CAPR warehouses are owned by the government, and no rent or any other type of compensation is paid for use of these storage facilities. Additionally, CENAME also rents storage space from the Cameroonian railway company. The logistics capacity of CENAME and the four regional warehouses (CAPRs) surveyed is summarized in Table 2.5.1.

At the regional level, the supply system is subdivided into three networks that supply (a) essential medicines at a fee (cost-recovery supply system), (b) ART commodities, and (c) PMTCT commodities. PMTCT and ART commodities are dispensed free of charge to clients. There are ten regional medical stores (CAPRs), whose main mission is to supply public health facilities with essential medicines and other health commodities in a cost-recovery supply system. CAPRs are also responsible for supplying ARVs to health facilities on a monthly basis. CAPRs receive $5 \%$ management fee for all ARVs procured with Global Fund and government funds, except for the fixed-dose emtricitabine + tenofovir + efavirenz, which is not provided free, however CAPRs do not receive any management fees for ARVs procured with CHAI funding. Though CENAME supplies all categories of medicines and other health commodities to CAPRs, including ARVs, since 2012 CAPRs no longer deliver ARVs and other PMTCT commodities to either health facilities or district health offices. [7] Whereas CENAME is responsible for warehousing and transportation to CAPRs of all categories of medicines and health products, CAPRs are responsible for these two logistics functions for all other categories of commodities-except ART and PMTCT commodities, which are not transported by CAPRs but rather have to be collected by the SDPs themselves.

The National AIDS Control Coordinating Committee (NACC) allocates ARVs to CAPRs based on available quantities. CENAME transports the allocated quantities of ARVs to CAPRs. NACC is organized into technical groups at central and regional levels. Reports on stock status and number of patients are sent from SDPs to the regional technical groups (RTGs) on a monthly basis. The monthly report is in an NACC-prescribed format.

As a consequence of shortage of ARVs during the last couple of years, the NACC has rationed PMTCT and ART commodities to SDPs based solely on quantities that could be procured with insufficient funding. This push model currently used for PMTCT and ART commodity supply includes transportation by CENAME to CAPRs and then collection of commodities from CAPRs by either district health service staff for PMTCT or ART dispensing site staff for ART commodities. HIV/AIDS commodities transported by CENAME to CAPRs, either on the basis of requisitions or allocations, are received by a committee. After arrival at CAPRs, PMTCT commodities are allocated to districts, from which SDPs collect their supplies.

At the district level, the standard practice for supply of PMTCT commodities is through requisitions, but owing to stock shortages, resupply is by allocation based on quantities of commodities that have been collected from CAPRs. Logistics capacity is generally lacking at the district health service level. Only one out of the ten districts surveyed in this study has one pick-up truck and that is over 15 years old. In some of the districts, staff members use their personal vehicles to transport PMTCT and ART commodities between CAPRs and treatment sites. 


\section{Materials and Methods}

Secondary and primary data collection was done through literature review of relevant reports, regulatory and policy documents, and administration of questionnaires. Primary data collection was carried out using a set of five questionnaires, addressed to operational staff at the target supply chain organizations at central, regional, and SDP levels in the public supply system, and at central level only for private sector logistics service providers. The questionnaires were developed for the purpose of this analysis, piloted and further customized, and then administered by trained data collectors. Warehouse storage capacity at all levels in the public health supply system was physically measured by data collectors.

The scope of the assessment included PMTCT, ART, the central warehouse (CENAME); four regional warehouses (CAPRs) in the four regions supported by the United States President's Emergency Plan for AIDS Relief (PEPFAR) in Center, Littoral, Northwest, and Southwest regions; a sample of 10 district health service stores; and 30 service delivery points (SDPs), including ART sites and antenatal clinics that offer PMTCT service within the four regions. The SDPs included health facilities that belong to public and private health providers such as faith-based organizations (FBOs). Seven private logistics providers were also included in the analysis. A total of 52 entities across public and private sectors were surveyed. Geographic locations of the SDPs are shown in the Appendix.

Primary quantitative and qualitative logistics data were entered into Census and Survey Processing System (CSPro) software and then analyzed using Epi-Info and Microsoft Excel. Qualitative data were analyzed manually by summarizing common themes, key relevant points, and examples found in interviewee responses.

\section{Costing Method}

Audited 2013 financial statements, including balance sheets collected from CENAME and CAPRs, provided supply chain cost data. These financial statements contained total supply chain management costs for all categories of medicines and other health commodities managed by these entities, including PMTCT and ART commodities. Only staff and transport costs were reported as distinct line items in the financial statements. Given that CENAME and CAPRs have only one mandate, which is health supply chain management, all other operating costs that were not itemized in the financial statements as either staff or transport costs were lumped into one category that was labeled as "Warehousing, inventory management, overhead costs" (warehousing and other costs). These three categories of supply chain costs were then used to calculate unit costs of staffing, transport, and warehousing and other costs, at CENAME and CAPRs. Table 1 list all logistics cost factors used in this analysis.

District store staffing, warehousing, and other logistics costs were assumed to be similar to those incurred by
CAPRs in 2013. However, unit transport costs were estimated based on annual costs and average distances between districts and CAPRs, and SDPs, which were provided by survey respondents.

To estimate supply chain management costs contributed by PMTCT and ART commodities at CENAME and CAPRs, the fractions of total storage space at these institutions that are dedicated to these commodities were used. For example, an average of $20 \%$ of total storage surface area available at CAPRs is dedicated to PMTCT and ART commodities; therefore it was estimated that $20 \%$ of total supply chain costs of CAPRs would be contributed by logistics management of these commodities.

In addition to using cost contribution to estimate logistics costs of PMTCT and ART commodities at CENAME and CAPR levels, cost data provided by respondents at district and SDP levels was used to calculate logistics costs at these levels of the public supply system. Details of the costing factors are shown in table 1 .

Annual overall operating costs and current and fixed assets at CENAME and CAPRs were extracted from the respective 2013 balance sheets and then analyzed to assess operational performance of these entities. Two metrics analyzed were "asset turnover" and "inventory turnover rate." Whereas asset turnover measures how well available assets are utilized - that is, efficiency - inventory turnover rate (how many times inventory rotates per annum) is a measure of productivity.

\subsection{Paper Title}

Addressing the Unmet Need for ART among HIV+ Women and Newborns in Cameroon through Strengthening the Supply Chain of PMTCT Commodities

\subsection{Authorship}

Emmanuel Nfor, Management Sciences for Health, Pharmaceuticals and Health Technologies Group/SIAPS, Arlington, VA 22203, United States, Email: enfor@msh.org; Kanjinga Kakanda, MSH, PHT/SIAPS, Arlington, VA, 22203, United States; Gege Buki, MSH, PHT/SIAPS, Kigali, Rwanda; Aline Kane, MSH, PHT/SIAPS, Yaoundé, Cameroon; Jean Dongang, MSH, PHT/SIAPS, Yaoundé, Cameroon

\subsection{Abstract \& Keywords}

See above.

\subsection{Figures (see attached)}

2.4.1. PMTCT and ART Supply Options Analysis

2.4.2. Asset turnover at CAPR Centre, Littoral, Northwest, and Southwest, based on 2013 balance sheets

2.4.3. Projected Storage Volume Requirements for HIV/AIDS Commodities, 2014-2017

2.4.4. Logistics costs based on 2015 forecasted quantities of PMTCT and ART commodities 
Table 1. Warehousing and transportation (logistics) Cost Factors

\begin{tabular}{|c|}
\hline Logistics cost factors between CENAME and CAPRs \\
\hline Staffing cost at CENAME was about XAF 6,177,000 per staff member per annum. \\
\hline Annual warehousing, inventory management, overhead costs at CENAME were about XAF 1,066,900 per unit storage space \\
\hline Annual transport [fuel + fleet maintenance] at CENAME was about XAF 106,749,700. \\
\hline $\begin{array}{l}\text { Total annual distance traveled by CENAME to deliver commodities to the four regional CAPRs surveyed, considering monthly deliveries, is about } \\
23,520 \text { kilometers }(\mathrm{km}) \text {. Total distance between CENAME and three CAPRs surveyed is } 980 \mathrm{~km} \text {; CAPR Centre region is located in the same } \\
\text { premises with CENAME. }\end{array}$ \\
\hline $\begin{array}{l}\text { Average monthly transport cost contribution for delivery of PMTCT and ART commodities by CENAME to each CAPR, based on } 2013 \text { financial } \\
\text { statement, is XAF } 62,270 \text {. This cost contribution is } 7 \% \text { of total annual transport cost at CENAME, which is based on the fact that } 7 \% \text { of } \\
\text { CENAME's total storage capacity is dedicated to PMTCT and ART commodities. }\end{array}$ \\
\hline $\begin{array}{l}\text { Total storage surface area at CENAME is } 3,795 \text { square meters. } \\
\text { Total storage surface area dedicated to PMTCT and ART commodities at CENAME is } 254 \text { square meters. }\end{array}$ \\
\hline Logistics cost factors between CAPRs and districts \\
\hline Staffing cost at CAPRs is about XAF 4,342,000 per staff member per annum. \\
\hline Average annual warehousing, inventory management, and overhead costs per unit storage space at CAPRs are about XAF 148,110 per cubic meter. \\
\hline Annual transport [fuel + fleet maintenance] at CAPRs is about XAF 7,800,000. \\
\hline Average distance traveled by each district to CAPRs to collect PMTCT and ART commodities is $334 \mathrm{~km}$. \\
\hline $\begin{array}{l}\text { Average monthly transport cost per district for PMTCT and ART commodities, as reported by interviewees, is XAF } 18,585 \text {; commodities are } \\
\text { transported by taxi or motorbikes. }\end{array}$ \\
\hline $\begin{array}{l}\text { Total number of districts in the four regions surveyed that have PMTCT and ART SDPs is } 86 . \\
\text { NB: Eleven districts in the four regions surveyed do not have SDPs for PMTCT and ART (CNLS). }\end{array}$ \\
\hline $\begin{array}{l}\text { Average storage space at CAPRs is } 251.7 \text { cubic meters, considering a usable storage height of } 2.5 \text { meters. This is about } 20 \% \text { of total available } \\
\text { storage capacity at each CAPR. Total storage volume dedicated to PMTCT and ART commodities at all four CAPRs surveyed is about } 1006.8 \\
\text { cubic meters. }\end{array}$ \\
\hline Logistics cost factors between CAPRs and SDPS \\
\hline $\begin{array}{l}\text { Average quarterly transport cost per CAPR is XAF } 482,585 \text {; this cost assumes CAPRs will deliver to the same SDPs as they did in } 2013 \text {. Maximum } \\
\text { annual transport cost per CAPR was obtained from financial statement of CAPR Northwest of XAF 9,651,625. } \\
\text { On average about } 264 \text { pharmacies are supplied by each CAPR under the cost-recovery supply system. These pharmacies are located at health } \\
\text { facilities that also offer PMTCT and ART services. }\end{array}$ \\
\hline $\begin{array}{l}\text { Logistics costs at SDPs were not included in this analysis because these costs will be the same for all options. However, these costs will have to be } \\
\text { added to determine total costs for the preferred option. }\end{array}$ \\
\hline Costing parameters for logistics between districts and SDPs \\
\hline Staffing unit cost obtained from financial statements provided by CAPRs was used to estimate costs at district stores. \\
\hline $\begin{array}{l}\text { Average distance traveled by SDPs to collect PMTCT and ART commodities from districts is } 41.5 \mathrm{~km} \text {. The farthest SDP from a district is about } 90 \\
\mathrm{~km} \text {. However, transport cost for this analysis was based on the average distance traveled between district and SDPs. }\end{array}$ \\
\hline $\begin{array}{l}\text { Average monthly return trip transport cost per SDP is XAF } 20,000 \text {. } \\
\text { Target number of SDPs is } 264 \text { per region (or per CAPR). Commodities may be transported by taxi, motorbikes, or private vehicles. }\end{array}$ \\
\hline $\begin{array}{l}\text { Average number of PMTCT/ART SDPs served by one district is } 12 \text {, which translates to about } 10 \text { SDPs given an estimated } 80 \% \text { PMTCT coverage } \\
\text { nationally (2010). } \\
\text { Average number of districts served by each CAPR is } 22 \text {. }\end{array}$ \\
\hline $\begin{array}{l}\text { Average storage space at district store dedicated to PMTCT and ART commodities is } 34.3 \text { cubic meters. On average, tota } \\
\text { district store is about } 52 \text { cubic meters. Therefore, } 66 \% \text { of district storage capacity is dedicated to PMTCT and ART commodi }\end{array}$ \\
\hline
\end{tabular}




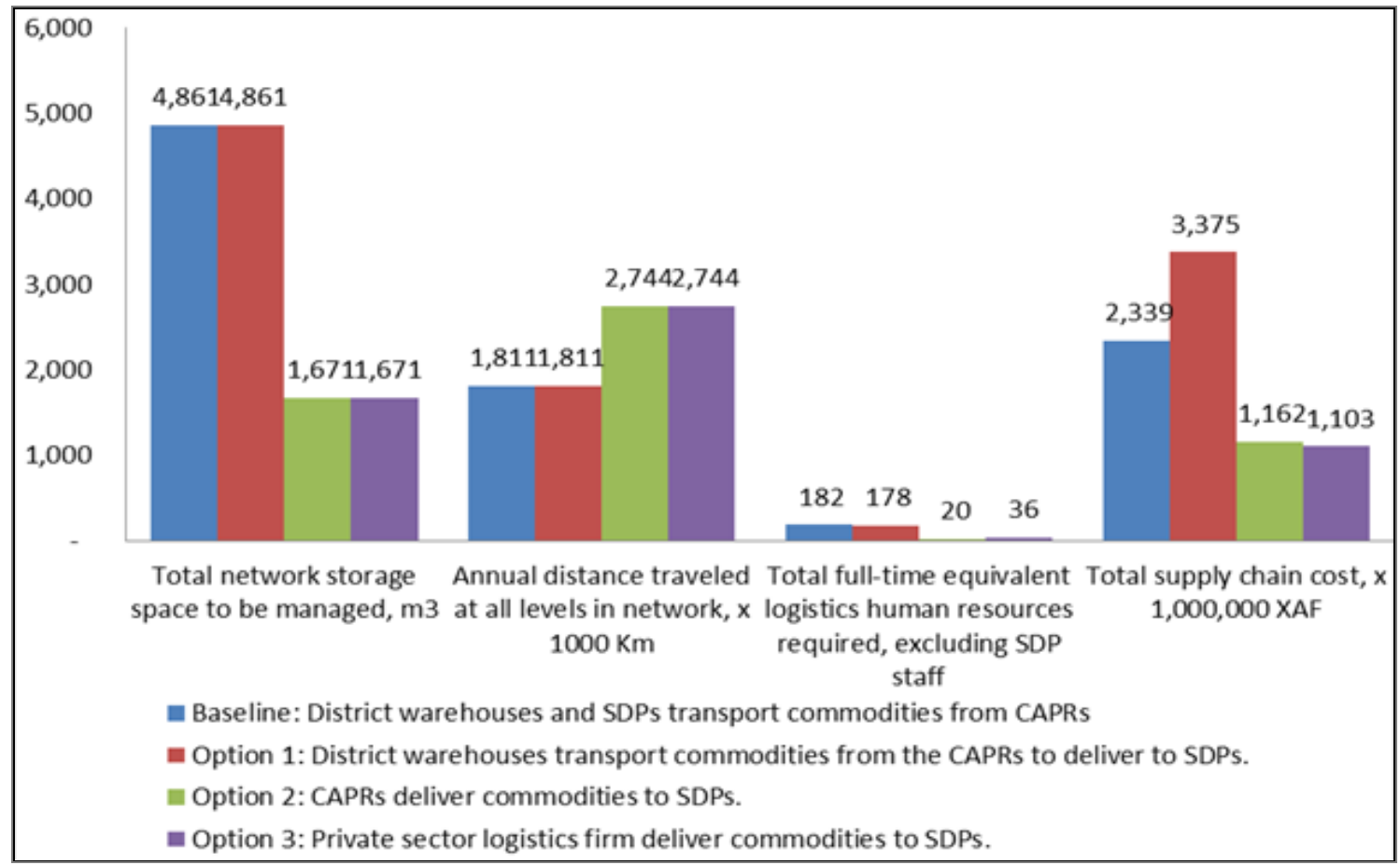

Figure 2.4.1. PMTCT and ART Supply Options Analysis

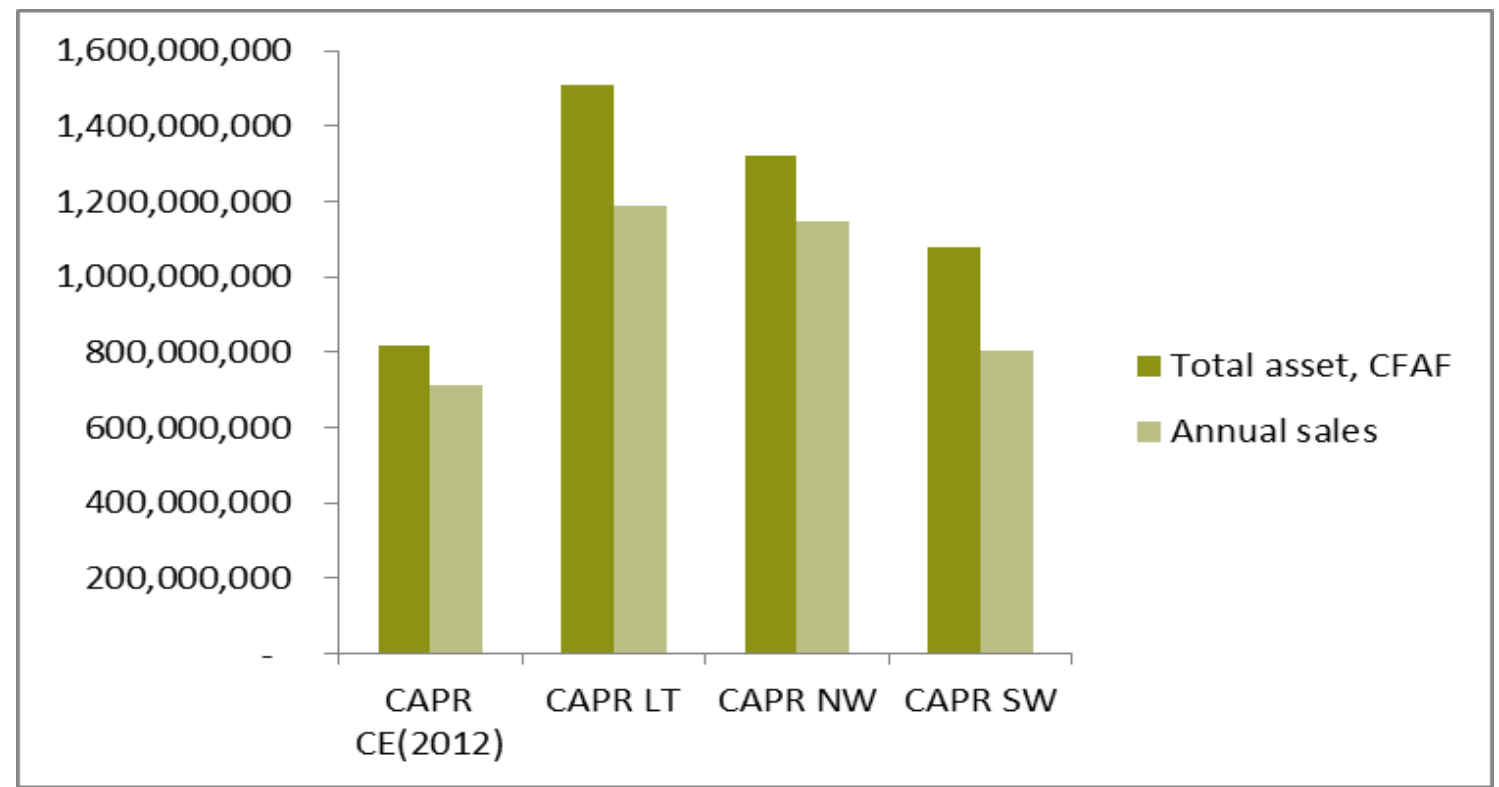

Figure 2.4.2. Asset turnover at CAPR Centre, Littoral, Northwest, and Southwest, based on 2013 balance sheets

\begin{tabular}{|c|c|c|c|c|}
\hline Product group & 2014 & 2015 & 2016 & 2017 \\
\hline ARVs PMTCT & 50 & 76 & 132 & 198 \\
\hline ARVs ART & 857 & 887 & 979 & 1,068 \\
\hline Laboratory reagents and supplies (without HIV RTKs) & 1,548 & 1,495 & 1,728 & 1,859 \\
\hline HIV RTKs & 94 & 94 & 110 & 118 \\
\hline OI medicines & 539 & 601 & 663 & 724 \\
\hline Total volume (cubic meters) & 3,088 & 3,153 & 3,612 & 3,967 \\
\hline
\end{tabular}

$\mathrm{OI}=$ opportunistic infection; $\mathrm{RTK}=$ rapid test kit

Figure 2.4.3. Projected Storage Volume Requirements for HIV/AIDS Commodities, 2014-2017 


\begin{tabular}{|c|c|c|c|c|c|c|c|c|}
\hline & \multirow{2}{*}{$\begin{array}{l}2015 \text { national } \\
\text { projected } \\
\text { storage } \\
\text { volume } \\
\text { requirement*, } \\
\text { m3 }\end{array}$} & \multirow{2}{*}{$\begin{array}{c}\text { Volume } \\
\text { require } \\
\text { ment } \\
\text { per unit } \\
\text { HIV } \\
\text { prevale } \\
\text { nce**, } \\
\text { m3 }\end{array}$} & \multirow{2}{*}{$\begin{array}{c}2015 \\
\text { projected } \\
\text { storage } \\
\text { volume } \\
\text { requirement } \\
\text { in } 4 \\
\text { PEPFAR-su } \\
\text { pported } \\
\text { regions**, } \\
\text { m3 [a] }\end{array}$} & \multicolumn{2}{|c|}{$\begin{array}{l}\text { Year } 2 \text { warehousing, inventory } \\
\text { management and overhead cost } \\
=[\mathrm{a}] \mathrm{x} \text { unit costs***; } \\
\text { [CENAME }=1,066,900 / \mathrm{m} 3 ; \\
\text { CAPRs }=148,110 / \mathrm{m} 3] ; \mathrm{XAF}\end{array}$} & \multicolumn{2}{|c|}{$\begin{array}{c}\text { Year } 2 \text { annual transport } \\
\text { cost }[\text { fuel }+ \text { maintenance]; } \\
\text { Considering inventory } \\
\text { turnover rate }=1 \text {; based on } \\
2013 \text { data) }\end{array}$} & \multirow{2}{*}{ Total } \\
\hline & & & & CENAME & 4 CAPRs & CENAME & 4 CAPRs & \\
\hline $\begin{array}{c}\text { PMTCT } \\
\text { ARVs }\end{array}$ & 76 & 2 & 31 & $33,073,900$ & $4,591,410$ & 348,866 & 48,024 & $38,062,200$ \\
\hline ART ARVs & 887 & 19 & 415 & $442,976,880$ & $61,495,272$ & $4,670,300$ & 642,900 & $509,785,351$ \\
\hline HIV RTKs & 94 & 2 & 44 & $46,943,600$ & $6,516,840$ & 495,165 & 68,163 & $54,023,767$ \\
\hline $\begin{array}{c}\text { OI } \\
\text { medicines }\end{array}$ & 539 & 11 & 252 & $269,178,870$ & $37,368,153$ & $2,835,941$ & 390,387 & $309,773,351$ \\
\hline $\begin{array}{c}\text { Total } \\
\text { CENAME } \\
+4 \text { CAPRs } \\
\end{array}$ & 1596 & & 743 & $792,173,250$ & $109,971,675$ & $8,350,271$ & $1,149,474$ & $\begin{array}{c}\text { XAF } 911,644,700 \\
\text { (US\$ } 1,914,455 \text { ) }\end{array}$ \\
\hline \multicolumn{8}{|c|}{$\begin{array}{l}\text { Total year } 2 \text { recurrent cost for about } 1056 \text { SDPs same as year } 1 \text {. Though PMTCT will be scaling up, ART program will } \\
\text { continue to operate at scale requiring continuous delivery of commodities to all SDPs. }\end{array}$} & $\begin{array}{c}\text { XAF } \\
5,364,662,700 \\
\text { (US\$ } 11,265,800)\end{array}$ \\
\hline
\end{tabular}

*Based on NACC quantification report (2014)

**Estimates take into consideration regional HIV prevalence in general population (DHS 2011), and regional HIV positivity rate in pregnant women (GTC-CNLS, 2013)

***warehousing, inventory management and overhead unit costs per $\mathrm{m} 3$ at CENAME and CAPRs were extracted from audited 2013 financial statements.

Figure 2.4.4. Logistics costs based on 2015 forecasted quantities of PMTCT and ART commodities

\section{Method Used to Estimate Storage Capacity Requirement}

Forecast quantities of ARVs and laboratory reagents required for 2014 to 2017 were used to evaluate storage space requirements for PMTCT and ART products (see National AIDS Control Committee [NACC] quantification). The forecast results are based on assumptions endorsed by the National AIDS Control Committee.

Product unit volumes, in cubic meters, were obtained from the supply chain management systems project procurement database. As much as possible, World Health Organization (WHO) prequalified formulations were selected, and when more than one WHO prequalified product with different unit volumes existed, the average was used for estimating the volume of the product. The capacity requirement for storage for each product was calculated by multiplying the annual forecast requirement by the unit volume of each product, and then summing the volume requirements for all products to estimate the total storage capacity required to hold maximum stock levels at CENAME and CAPRs. In cases where unit volumes were not available for a specific product and package, unit volumes from similar products and packaging were used as a proxy.

The forecast results based on scenario 2 assumptions were applied for ART and ARV requirements.

For HIV laboratory supplies, and test kits, unit volumes were not available for 13 of 204 products (6.37\%). Thus, the volumes represent $94 \%$ of the HIV/AIDS products considered.

\subsection{Tables (see attached)}

2.5.1. Logistics Capacity of CENAME and Four CAPRs (Central, Littoral, Northwest, and Southwest) Regions

2.5.2. Inventory Turnover Rate at CENAME and CAPR Centre, Littoral, Northwest, and Southwest, 2013

\subsubsection{Tables Numbering \& Citation}

Tables in the main body of the text should be numbered consecutively according to its appearance in the text. Cite each table in numerical order.

\subsection{Figures (see attached)}

\subsection{Appendix}

See attached maps of four surveyed regions.

\subsection{Reference Style}

\section{Books}

NA

\section{Journals}

NA 


\section{Conclusions}

As a result of dissemination of the findings, the Ministry of Health actually adopted Option 2. PMTCT free of charge commodities are also amenable for being managed within the existing effective cost recovery system.

\section{Acknowledgements}

The authors are grateful for the good collaboration of the Cameroon NACC, staffs of CANAME, CAPRs, Regional and District Health offices and the SDPs, in the planning, data collection and analysis phases of this study, and for their participation in dissemination of the results of this analysis. Further thanks to the USAID Cameroon office for funding the study.

Table 2.5.1. Logistics Capacity of CENAME and Four CAPRs (Central, Littoral, Northwest, and Southwest) Regions, 2014

\begin{tabular}{|c|c|c|c|c|c|c|c|}
\hline $\begin{array}{l}\text { Entity/ } \\
\text { resource }\end{array}$ & $\begin{array}{c}\text { Total storage } \\
\text { surface area } \\
\text { (square meters) }\end{array}$ & $\begin{array}{c}\text { Storage surface area } \\
\text { dedicated to PMTCT } \\
\text { and ART commodities } \\
\text { (square meters) }\end{array}$ & \begin{tabular}{|c|} 
Mechanized \\
material handling \\
equipment \\
(number \\
available)
\end{tabular} & $\begin{array}{c}\text { Logistics management } \\
\text { information system } \\
\text { (paper, electronic, } \\
\text { mixed) }\end{array}$ & $\begin{array}{l}\text { Transport capacity, } \\
\text { truck type (number } \\
\text { functional) }\end{array}$ & $\begin{array}{c}\text { Pharmaceutical } \\
\text { waste disposal } \\
\text { facilities }\end{array}$ & $\begin{array}{c}\text { Total } \\
\text { number of } \\
\text { staff }\end{array}$ \\
\hline CENAME & 3,795 & $254(7 \%)$ & $\begin{array}{l}\text { Hand pallet } \\
\text { trucks } \\
(6)\end{array}$ & $\begin{array}{c}\text { Paper and electronic } \\
\text { systems }\end{array}$ & $\begin{array}{l}\text { Heavy-weight truck (1); } \\
\text { 2-ton pickup truck (2); } \\
\text { container pickup truck } \\
(1)\end{array}$ & \begin{tabular}{|c|} 
None \\
available; \\
destruction by \\
HYSACAM \\
\end{tabular} & 90 \\
\hline CAPR Central & 453 & $105(23 \%)$ & \begin{tabular}{|} 
Hand pallet \\
trucks (2); hand \\
trolleys (2)
\end{tabular} & $\begin{array}{l}\text { Paper and electronic } \\
\text { systems }\end{array}$ & $\begin{array}{l}3.5 \text {-ton truck (1); } \\
2.5 \text {-ton truck ( } 3)\end{array}$ & \begin{tabular}{|c|} 
None \\
available; \\
destruction by \\
HYSACAM \\
\end{tabular} & 33 \\
\hline CAPR Littoral & 769.3 & $192.3(25 \%)$ & \begin{tabular}{|c|} 
Hand pallet \\
trucks (4); hand \\
trolleys (3)
\end{tabular} & $\begin{array}{l}\text { Paper and electronic } \\
\text { systems }\end{array}$ & 2.5 -ton truck (4) & None available & 27 \\
\hline $\begin{array}{c}\text { CAPR } \\
\text { Northwest }\end{array}$ & 479 & $70.8(15 \%)$ & $\begin{array}{l}\text { Hand trolleys } \\
\text { (11) }\end{array}$ & $\begin{array}{l}\text { Paper and electronic } \\
\text { systems }\end{array}$ & $\begin{array}{l}3.5 \text {-ton truck (3); } \\
2.5 \text {-ton truck (1) }\end{array}$ & None available & 35 \\
\hline $\begin{array}{c}\text { CAPR } \\
\text { Southwest }\end{array}$ & 193.3 & $34.6(18 \%)$ & \begin{tabular}{|c|} 
Hand pallet \\
trucks (9); hand \\
trolleys (1)
\end{tabular} & $\begin{array}{c}\text { Paper and electronic } \\
\text { systems }\end{array}$ & $\begin{array}{l}2.5 \text {-ton truck (4); } \\
1.5 \text {-ton truck (1) }\end{array}$ & None available & 22 \\
\hline
\end{tabular}

HYASCAM = Hygiène et Salubrité du Cameroun

Table 2.5.2. Inventory Turnover Rate at CENAME and CAPR Centre, Littoral, Northwest, and Southwest, 2013

\begin{tabular}{|c|c|c|c|c|c|}
\hline Formula/Supply chain entity & CENAME (2012) & CAPR Centre (2012) & CAPR Littoral & CAPR Northwest & CAPR Southwest \\
\hline $\begin{array}{c}\text { Sales revenue/average } \\
\text { inventory valued at selling } \\
\text { price }\end{array}$ & 1.11 & 2.27 & 1.01 & 1.58 & 1.21 \\
\hline $\begin{array}{c}\text { Cost of goods sold/average } \\
\text { inventory valued at cost }\end{array}$ & 2.31 & 1.87 & 1.00 & 1.41 & 1.16 \\
\hline
\end{tabular}




\section{Appendix}
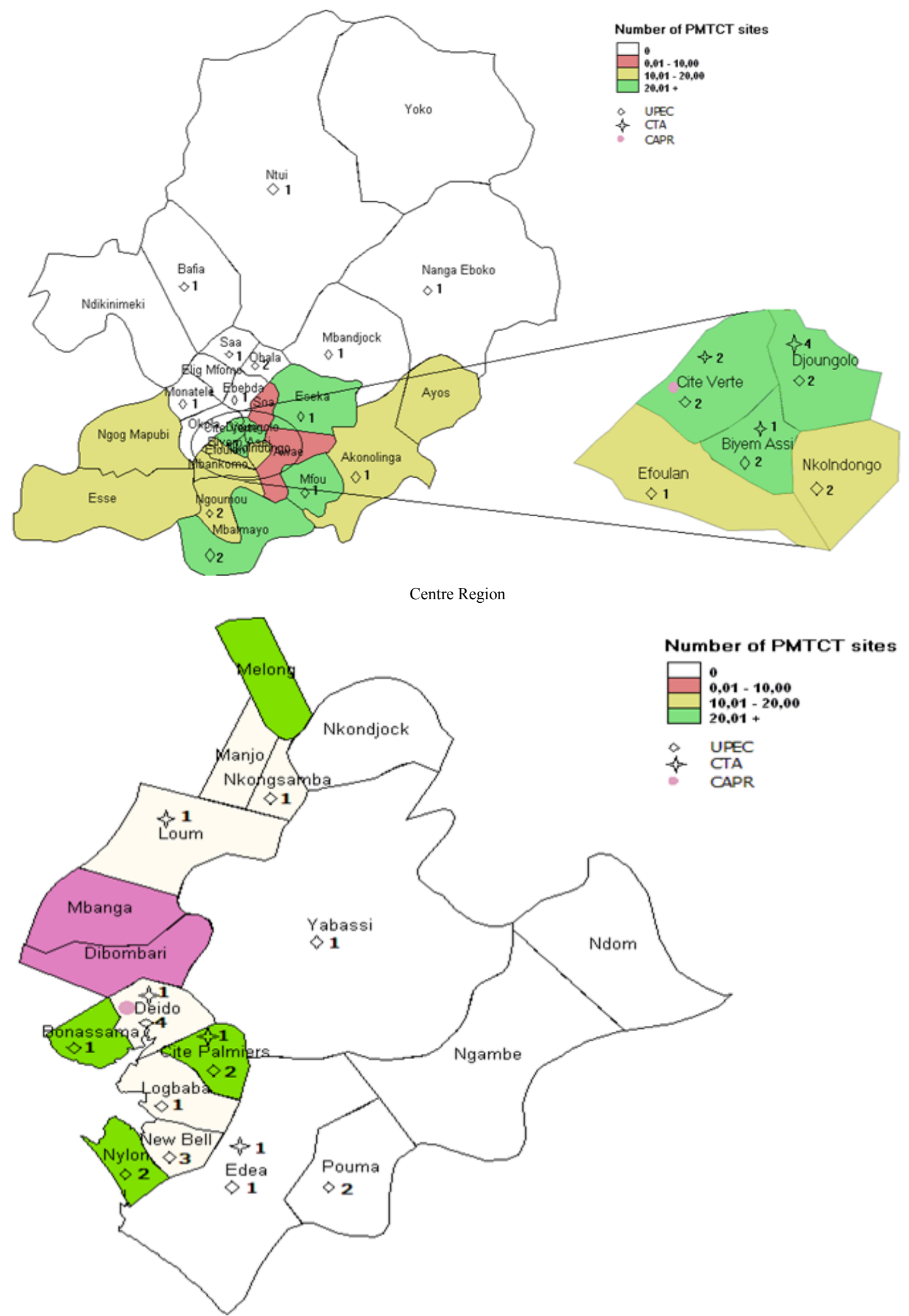

Littoral Region 


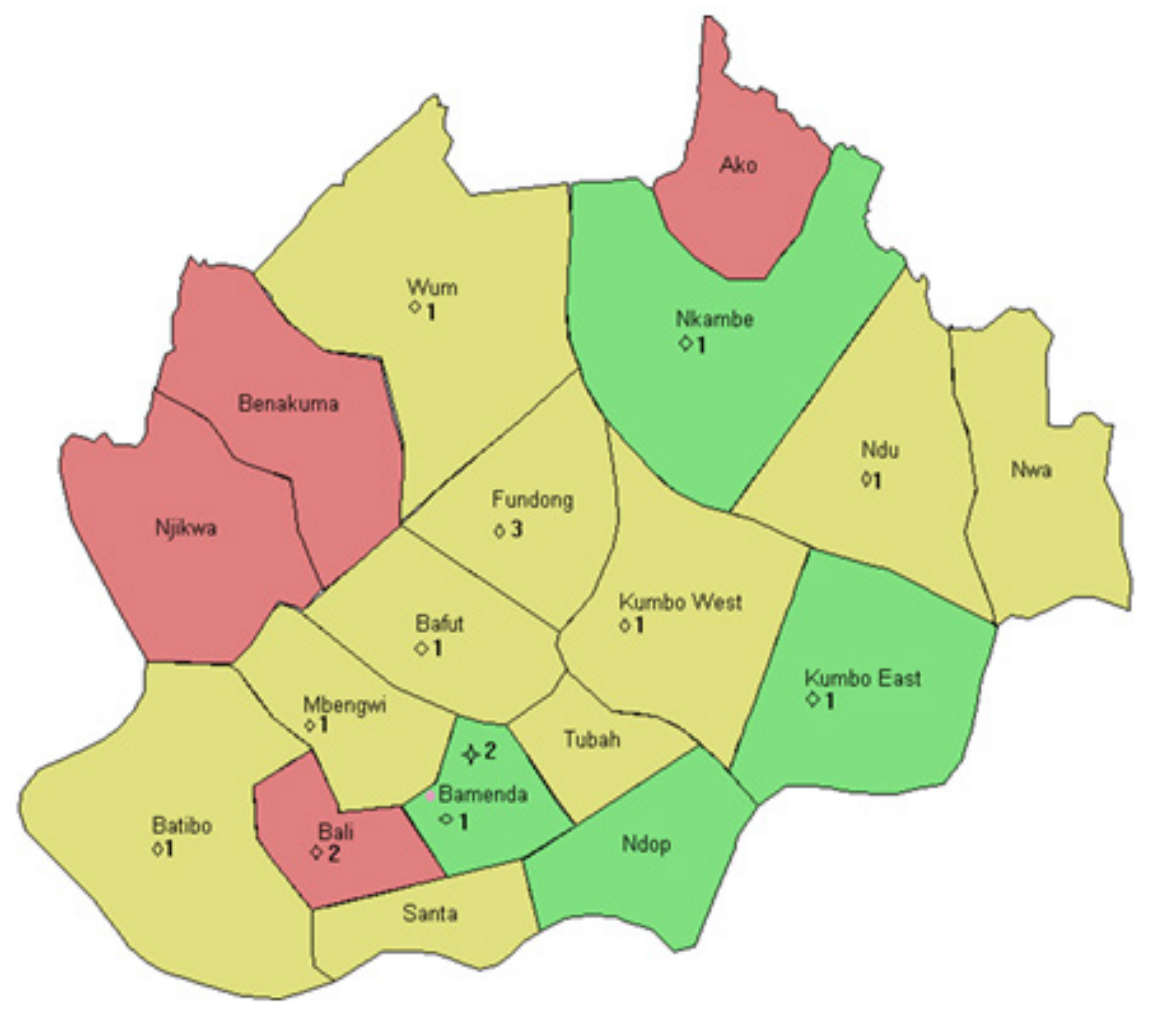

Number of PMTCT sites

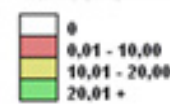

\& UPEC

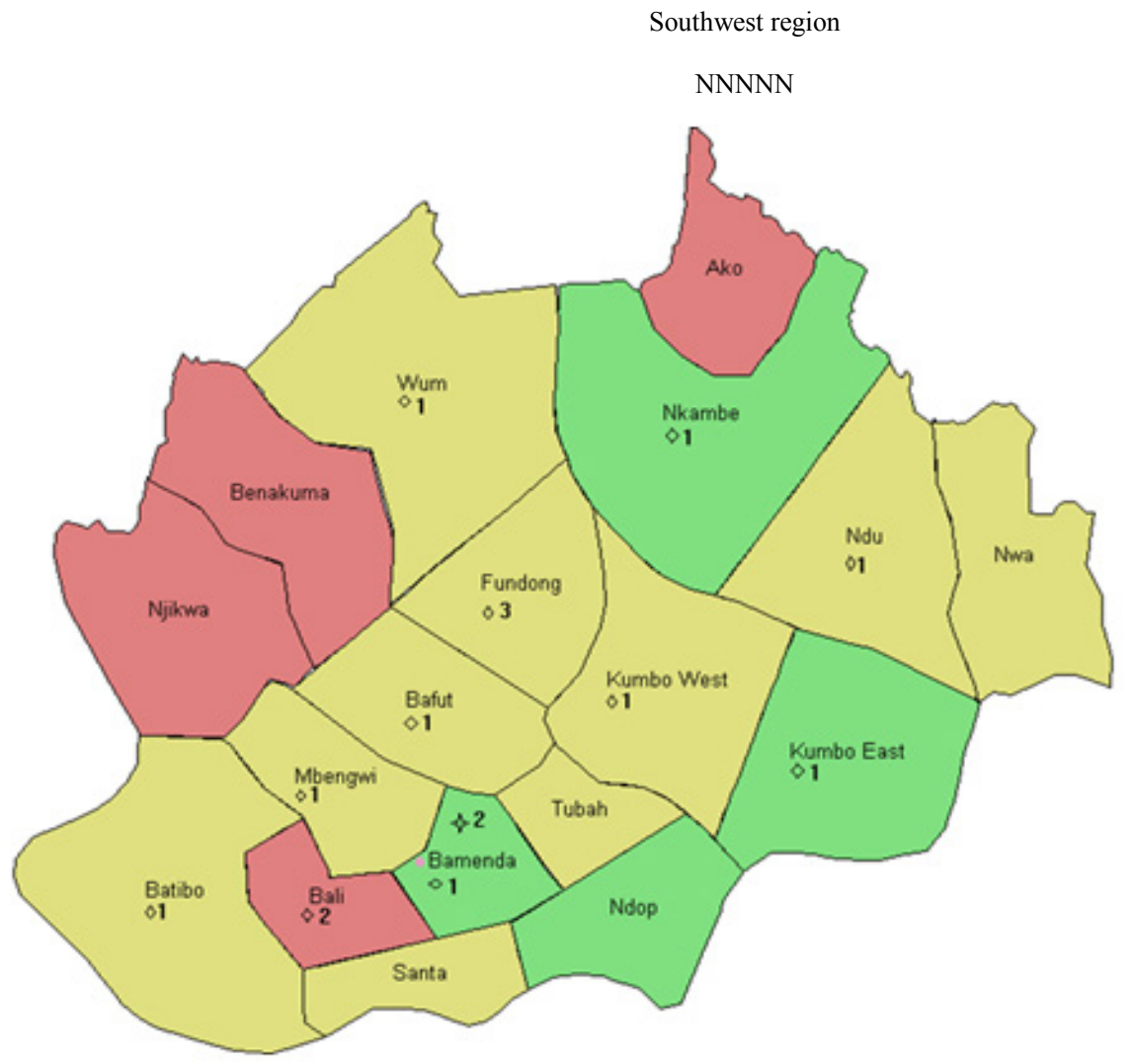

Number of PMTCT sites

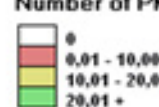

\& UPEC

Northwest Region 


\section{REFERENCES}

[1] Kojoué Kamga L. Orphans, AIDS, and the Millennium Development Goals: Models and Capacity to act, Sante Vol. 19, No 3, Jul-Aug- Sept, 2009

[2] Lawson GW. Keirse MJ. Reflections on the maternal mortality millennium goal, Birth, Volume 40, Issue 2, pages 96-102, June 2013

[3] Ministère de la Santé Publique du Cameroun. Plan National d'Elimination de la Transmission Mère-Enfant du VIH à l'Horizon 2015 au Cameroun, 2012
[4] Ministère de la Santé Publique du Cameroun, Comité National de Lutte contre le SIDA. 2011. Vers l'Élimination Virtuelle de la Transmission du VIH de la Mère a L'Enfant à l'Horizon 2015.

[5] Ministère de la Santé Publique du Cameroun, Comité National de Lutte contre le SIDA, Rapport Préliminaire de l'Enquête PMTCT Facility au Cameroun, 2012.

[6] Common Wealth Online. Child and Maternal Health in Cameroon, available at: http://www.commonwealthhealth.or $\mathrm{g} /$ africa/cameroon/child_and_maternal_health_in_cameroon/ (accessed 11 August 2014)

[7] Management Sciences for Health's Systems for Improved Access to Pharmaceuticals and Services (SIAPS) Program. Assessment of Storage and Distribution Capacity of Pharmaceutical Warehouses in Cameroon, Report on Findings, 2012 